\title{
Bird attributes, plant characteristics, and seed dispersal of Pera glabrata (Schott, 1858), (Euphorbiaceae) in a disturbed cerrado area
}

\author{
Francisco, MR. ${ }^{\mathrm{a} *}$, Lunardi, $V O .^{\mathrm{b}}$ and Galetti, $M .^{\mathrm{c}}$
}

${ }^{a}$ Campus de Sorocaba, Universidade Federal de São Carlos, CEP 18043-970, CP 3031, Sorocaba, SP, Brazil

'Departamento de Genética e Evolução, Universidade Federal de São Carlos, CP 676, CEP 13565-905, São Carlos, SP, Brazil

'Plant Phenology and Seed Dispersal Research Group, Laboratório de Biologia da Conservação, Departamento de Ecologia, Universidade Estadual Paulista,

CEP 13506-900, Rio Claro, SP, Brazil and Instituto de Biologia da Conservação, IBC, Campinas, SP, Brazil

*e-mail: mercival@power.ufscar.br

Received June 23, 2005 - Accepted April 17, 2006 - Distributed November 30, 2007

\begin{abstract}
Several plant characteristics, such as fruit production, nutrient reward, secondary compounds, and fruit color display, affect fruit choice by birds. On the other hand, several bird attributes affect their efficiency as dispersers. Here we investigate the ornithochoric seed dispersal of Pera glabrata Schott (Euphorbiaceae) in a cerrado fragment in southeastern Brazil. A set of bird attributes, such as frequency of visits, number of diaspores eaten, time spent foraging, methods of taking and handling the diaspores and agonistic interactions were analyzed in order to infer about the potential of each species to act as a seed disperser. Birds were the unique seed dispersers of these oil-rich diaspores. We observed 414 bird visits during 60 hours of focal observations in five trees from December 1999 to January 2000. Twenty bird species from seven families ate the diaspores of P. glabrata, but only 14 species were considered potential seed dispersers because they swallowed the diaspores, increasing the probabilities for the seeds to be defecated and/or regurgitated away from the parent trees. The main potential seed dispersers were: Turdus leucomelas (Muscicapidae), Dacnis cayana (Emberizidae), Colaptes melanochloros (Picidae) and Elaenia spp. (Tyrannidae). We did not find any significant seasonal change in the number of visits on the fruiting trees throughout the day. We also did not find any relation between the number of visits per tree and fruit production. The most effective seed dispersers of $P$. glabrata were generalist birds, which have a high visiting rate, high fruit consumption rate, and spend short periods on the plants. The large number of species recorded as potential seed dispersers of $P$. glabrata, being most of them very abundant even in Brazilian disturbed areas, may guarantee seed dispersal of this plant in small fragments and regenerating areas.
\end{abstract}

Keywords: cerrado, frugivory, fragmentation, ornithochory, seed dispersal.

\section{Características dos propágulos, atributos das aves, e a dispersão das sementes de Pera glabrata (Schott, 1858) (Euphorbiaceae) numa área degradada de cerrado}

\begin{abstract}
Resumo
As diferentes espécies de plantas apresentam características que podem influenciar na atração das aves frugívoras, como a quantidade de frutos produzidos, o valor nutritivo dos frutos, a presença de compostos secundários e o display de cores. Por outro lado, diversos estudos têm demonstrado que as espécies de aves que consomem frutos não apresentam a mesma eficiência como dispersores das sementes. Embora estudos sobre a frugivoria e dispersão de sementes sejam de grande importância para a realização de planos de manejo e recuperação de áreas degradadas, pouco tem sido pesquisado sobre o assunto no cerrado brasileiro. Neste trabalho são apresentados aspectos da frugivoria e dispersão ornitocórica das sementes de Pera glabrata Schott (Euphorbiaceae) num fragmento de cerrado do sudeste do Brasil. Atributos das aves, como frequiência de visitas, número de diásporos consumidos, tempo de permanência sobre as plantas, métodos de captura e mandibulação dos diásporos, bem como interações antagônicas, foram analisados para se inferir sobre o potencial de cada espécie para atuar como dispersora das sementes. As aves foram os únicos potenciais dispersores dos diásporos. Em 60 horas de observações focais, realizadas entre dezembro de 1999 e janeiro de 2000 , foram registradas 414 visitas de 20 espécies de aves pertencentes a sete famílias. No entanto, apenas 14 destas espécies foram consideradas como potenciais dispersores. Os principais potenciais dispersores foram Turdus leucomelas (Muscicapidae), Dacnis cayana (Emberizidae), Colaptes melanochloros (Picidae) e Elaenia spp. (Tyrannidae). O número de visitas não diferiu significativamente entre os diferentes intervalos de hora do dia. Não foi encontrada correlação significativa entre o número de visitas e o número de frutos presentes em cada árvore. As aves
\end{abstract}


generalistas foram as principais potenciais dispersoras de . glabrata, tendo apresentado altas taxas de visitação, alto consumo de diásporos, e permaneceram sobre as plantas durante curtos períodos de tempo. Muitas das espécies de aves observadas são bastante abundantes mesmo em ambientes antrópicos, o que deve garantir a dispersão das sementes de P. glabrata em pequenos fragmentos e em áreas que se encontram em estágio de recuperação.

Palavras-chave: cerrado, frugivoria, fragmentação, ornitocoria, dispersão de sementes.

\section{Introduction}

Seed dispersal is a key element in plant demography and survival (Herrera et al., 1994; Wenny and Levey, 1998; Tabarelli et al., 1999; Passos and Oliveira, 2002), and it is well known that most Neotropical tree and shrub species attract birds and mammals to disperse their seeds (Jordano, 1992; Pinheiro and Ribeiro, 2001).

Several plant characteristics, such as fruit production, nutrient reward, secondary compounds, and fruit color display, affect the fruit attractiveness of birds (Izhaki, 2002). On the other hand, a set of bird attributes determine their efficiency as dispersers, such as gape size, time spent foraging, gut retention time, fruit handling behavior, among others (Pratt and Stiles, 1983; Wheelwright, 1985; Foster, 1987; Levey, 1987; Wenny and Levey, 1998). Moreover, the interactions between frugivorous birds and fruits may be affected by habitat disturbance (Howe, 1984; Pizo, 1997; Galetti and Aleixo, 1998; Tabarelli et al., 1999) and it is paramount to understand the seed dispersal system of vascular plants in natural ecosystems.

Forest fragmentation, for instance, may alter the composition of bird seed-disperser assemblages and the relative contribution of some species as dispersers (Pizo, 1997; Cardoso and Tabarelli, 2000), which can ultimately modify the demography and spatial distribution of the plant populations (Howe, 1984; Tabarelli et al., 1999). Bird-dispersed trees that produce large fruits with large seeds usually depend on a small guild of large-bodied primarily frugivorous birds to disperse their seeds (Howe, 1993). However, large frugivorous birds such as trogons, toucans and cotingas, are among the first species to disappear in disturbed habitats (Willis, 1979; Ribon et al., 2003), resulting in the decline of the recruitment with specialized seed dispersal systems (Cardoso and Tabarelli, 2000). On the other hand, opportunist birds are expected to provide effective dispersal for generalist plant species that by virtue of extended seed dormancy, resistance of seeds or seedlings to density-dependent mortality, or gap colonization strategy, demand requirements that can be found in a wide variety of dispersal agents (for a revision see Howe, 1993). Therefore, plant and disperser characteristics are predicted to determine the effectiveness of seed dispersal in disturbed habitats (Francisco and Galetti, 2001, 2002a, 2002b).

Studies on frugivory and seed dispersal in small remnants may provide valuable information, pointing out plant species that would have their seeds dispersed in such disturbed areas, assisting in the choice of plants to be used in reforestations, especially in locations where the large and specialized frugivorous animals were extinct (Pizo, 2004).

Although the interaction between fruits and birds has been intensively studied in Neotropical forests (Howe, 1977; Wheelwright, 1985; Foster, 1987, 1990; Galetti and Stotz, 1996; Pizo, 1997; Wenny and Levey, 1998; Passos and Oliveira, 2002), there is little information on seed dispersal by birds in other biomes, such as the Brazilian cerrado (Motta-Junior and Lombardi, 1990; Francisco and Galetti, 2001; Cazetta et al., 2002; Francisco and Galetti, 2002a, 2002b). Here we investigate the ornithochoric seed dispersal of Pera glabrata Schott (Euphorbiaceae) in a cerrado fragment in southeastern Brazil. A set of bird attributes, such as frequency of visits, number of diaspores eaten, time spent foraging, methods of taking and handling the diaspores and agonistic interactions were analyzed in order to infer about the potential of each species to act as a seed disperser.

\section{Material and Methods}

\subsection{Study site}

We studied the seed dispersal system of $P$. glabrata in a cerrado fragment that belongs to the campus of São Carlos Federal University, in São Paulo state, southeastern Brazil ( $21^{\circ} 58^{\prime} \mathrm{S}$ and $\left.47^{\circ} 52^{\prime} \mathrm{W}\right)$. The area has 124.68 ha of cerrado vegetation, 3.60 ha of gallery forests, 93.84 ha of Eucalyptus spp. plantations with dense cerrado understory and 222.73 ha of Eucalyptus spp. plantations with no understory (Paese, 1997). This area is disturbed, being sporadically affected by Eucalyptus logging and occasional fires. However, this study site is known to have 223 bird species (Motta-Junior and Vasconcellos, 1996) and 33\% of all species are known to eat fruits (Willis, 1979; Motta-Junior, 1990).

\subsection{Pera glabrata Schott}

Pera glabrata is a tree about $8 \mathrm{~m}$ high which is distributed in the cerrado, gallery forests and semideciduous forests in Brazil (Lorenzi, 1998), being also commonly found in disturbed and secondary habitats (personal observation). The fruits are round dehiscent capsules on which one to three black ellipsoid seeds are covered by a red oily aril, attractive to many bird species (Galetti and Pizo 1996). Seed production is irregular, not occurring every year (Lorenzi, 1998).

\subsection{Focal observations}

We observed five adult trees that produced about $2,800,4,300,9,600,18,000$ and 35,800 fruits when we 
started the study in December 1999. Fruit production was estimated by direct counting. We counted the fruit production at the beginning of the fruit season, just before the fruits started opening their capsules. All of the studied trees were located in the cerrado, alongside the borders of the gallery forests. These plants were at least $30 \mathrm{~m}$ apart from other $P$. glabrata.

Our study was carried out from December, 1999 to January, 2000, totalling $60 \mathrm{~h}$ of focal observations. On each focal day, we spent 12 hours (from 6:00 AM to 6:00 PM) per tree. For each bird visit on P. glabrata, we recorded the species observed, number of diaspores eaten, time when the birds arrived at the fruiting tree, time spent foraging, methods of taking and handling fruits and agonistic interactions between the individuals (Pizo, 1997).

The number of diaspores eaten and the time the birds spent foraging were determined when we had the complete observation of the whole behavior, i.e. from their arrival up until the departure from the fruiting tree (MottaJunior and Lombardi, 1990; Francisco and Galetti, 2001, 2002a, 2002b). We calculated the relative percentage of fruit consumption for each species by: 1) multiplying the mean number of fruits consumed per visit by the total number of visits; 2) dividing this value by the sum of the values obtained for all the species; and 3) multiplying the result by 100 .

We considered agonistic encounters when we observed the birds fighting or chasing other individuals. We used Willis (1979) and Motta-Junior (1990) to classify the diet of the species, and Motta-Junior and Vasconcellos (1996) to determine the migratory status of the species in the study site. Data from the weight of the birds were obtained from Marini et al. (1997) and Sick (1997). Taking and handling behavior was categorized according to Moermond and Denslow (1985).

\subsection{Statistical analyzes}

We used the non-parametric Kruskal-Wallis test to assess hourly differences in the number of visits and to compare the time spent foraging, as well as the number of diaspores eaten by the different bird species. Spearman rank correlation was used to test for correlation between: the number of fruits per plant and the number of visits; the time spent foraging and the number of diaspores consumed; and bird body mass and the number of diaspores eaten, which were then verified using the mean values of weights of the birds and the mean number of fruits consumed by each species. All of the analyses were performed using the software BIOESTAT 2.0 (Ayres et al., 2000). Those species with three or less complete observations were not included in the analyses.

\section{Results}

We found ripe fruits of $P$. glabrata from November 1999 to February 2000 in the study area. Fruit length was $10.89 \pm 1.37 \mathrm{~mm}$ (mean $\pm \mathrm{SD})$ and width $11.36 \pm 0.53 \mathrm{~mm}$ $(\mathrm{n}=10)$. The diaspore (aril + seed) length was $5.70 \pm$ $0.64 \mathrm{~mm}$, width $4.38 \pm 0.59 \mathrm{~mm}$, and weight $0.03 \pm 0.01 \mathrm{~g}$.
Seeds represented $58.7 \pm 10.3 \%$ of the weight of the diaspores $(n=17)$. A positive correlation between the length and diameter of the seeds was found (Spearman rank correlation test, $\mathrm{r}_{\mathrm{s}}=0.62, \mathrm{p}=0.0071$ ).

In 60 hours of observations, we recorded 20 bird species, belonging to seven different families, eating the diaspores (Table 1). Fourteen species swallowed the diaspores, increasing the probabilities for the seeds to be defecated and/or regurgitated away from the parent trees (Table 2). We recorded 414 bird visits and a mean of $6.9 \pm 6.7(n=60)$ visits per hour. The total observation period seemed to be enough to sample the main visitors of $P$. glabrata, since the maximum number of species was reached after 41 hours.

The pale-breasted thrush, Turdus leucomelas (Vieillot, 1818) (Muscicapidae) was the main potential seed disperser, consuming $16.6 \%$ of all diaspores observed, followed by the blue dacnis, Dacnis cayana (Linnaeus, 1766) (Emberizidae) (16.2\%) and the green-barred woodpecker, Colaptes melanochloros (Gmelin, 1788) (Picidae) (13.6\%). Other species comprised $44.2 \%$ of the diaspores consumed. Generalist species were responsible for the removal of $61.5 \%$ of all diaspores, followed by typical insectivores $(24.9 \%)$, seed predators $(9.4 \%)$, nectarivores (2.6\%) and primarily frugivores (1.6\%). Non-dispersers comprised $17.3 \%$ of all diaspores removed. Three species, the variegated flycatcher, Empidonomus varius (Vieillot, 1818) (Tyrannidae) and the red-eyed vireo, Vireo olivaceus (Linnaeus, 1766) (Vireonidae) were considered migratory in the study area (Table 1) and were responsible for the consumption of $9.5 \%$ of the diaspores.

Birds presented variable behavioral categories to take the diaspores of $P$. glabrata, and 18 species used more than two different categories (Table 2). We found no hourly difference in the number of visits when all of the species were analyzed together (Kruskal-Wallis: $\mathrm{KW}=14.24, \mathrm{p}=0.22)$, as well as when the most frequent species, such as D. cayana $(\mathrm{KW}=7.64, \mathrm{p}=0.74)$, elaenias, Elaenia spp. (Tyrannidae) $(\mathrm{KW}=14.88$, $\mathrm{p}=0.18)$, T. leucomelas $(\mathrm{KW}=12.04, \mathrm{p}=0.36)$ and $V$. oliveceus ( $\mathrm{KW}=7.84, \mathrm{p}=0.72$ ) were individually analyzed.

No correlation was found between the number of fruits from each plant and the number of visits $\left(r_{s}=0.80\right.$, $\mathrm{p}=0.13)$. The different bird species did not differ in the time they spent on the plants $(\mathrm{KW}=15.53, \mathrm{p}=0.16)$.

The number of fruits consumed differed significantly among the bird species $(\mathrm{KW}=27.43, \mathrm{p}=0.004)$, however, no significant correlation was found between the weight of the different species and the mean number of fruits consumed $\left(r_{s}=0.47, p=0.12\right)$. The time spent on plants and the number of fruits consumed were positively correlated for Elaenia spp. $\left(\mathrm{r}_{\mathrm{s}}=0.65, \mathrm{p}=0.021\right), D$. cayana $\left(r_{s}=0.80, p=0.0072\right)$, V. olivaceus $\left(r_{s}=0.95\right.$, $\mathrm{p}=0.0001$ ) and Z. capensis (Statius Muller 1776) $\left(r_{s}=0.82, p=0.015\right)$. For T. leucomelas, sayaca tanager, Thraupis sayaca (Linnaeus 1766) (Emberizidae) and burnished-buff tanager, Tangara cayana (Linnaeus, 1766) 
Table 1. Diet, migratory status, number of visits, number of diaspore taken, time spent on plants and number of visited plants by birds visiting Pera glabrata. Phylogenetic sequence follows Sick (1997).

\begin{tabular}{|c|c|c|c|c|c|c|c|}
\hline Species & $\begin{array}{c}\text { Visit } \\
\text { number }\end{array}$ & Diet $^{\mathrm{a}}$ & Status $^{b}$ & $\mathbf{N}^{\mathrm{c}}$ & Diaspore taken $^{\mathrm{d}}$ & $\begin{array}{c}\text { Time spent on } \\
\text { plants }^{\mathrm{e}}\end{array}$ & $\begin{array}{c}\text { Number } \\
\text { of visited } \\
\text { plants }\end{array}$ \\
\hline \multicolumn{8}{|l|}{ Seed dispersers } \\
\hline \multicolumn{8}{|l|}{ PICIDAE } \\
\hline Colaptes melanochloros & 14 & INS & $\mathrm{R}$ & 4 & $13.75 \pm 6.29$ & $101.25 \pm 33.21$ & 3 \\
\hline \multicolumn{8}{|l|}{ TYRANNIDAE } \\
\hline Elaenia spp. & 73 & ONI & $\mathrm{R}$ & 12 & $2 \pm 1.28$ & $48.5 \pm 31.45$ & 5 \\
\hline Myiarchus ferox & 2 & INS & $\mathrm{R}$ & 2 & $2.5 \pm 0.70$ & $59.5 \pm 36.06$ & 1 \\
\hline Myiarchus tyrannulus & 14 & INS & $\mathrm{R}$ & 4 & $5.5 \pm 1.29$ & $110.25 \pm 55.72$ & 4 \\
\hline Empidonomus varius & 13 & INS & M & 4 & $2.5 \pm 4.36$ & $46.5 \pm 64.16$ & 3 \\
\hline \multicolumn{8}{|l|}{ PIPRIDAE } \\
\hline Antilophia galeata & 7 & FRU & $\mathrm{R}$ & 4 & $3.25 \pm 1.70$ & $41.75 \pm 27.53$ & 1 \\
\hline \multicolumn{8}{|l|}{ CORVIDAE } \\
\hline Cyanocorax chrysops & 3 & ONI & $\mathrm{R}$ & 3 & $8.66 \pm 8.50$ & $102.0 \pm 121.74$ & 1 \\
\hline \multicolumn{8}{|l|}{ MUSCICAPIDAE } \\
\hline Turdus leucomelas & 45 & ONI & $\mathrm{R}$ & 10 & $5.5 \pm 5.25$ & $95.6 \pm 77.96$ & 4 \\
\hline Turdus amaurochalinus & 11 & ONI & $\mathrm{R}$ & 4 & $8.5 \pm 6.60$ & $70.25 \pm 78.41$ & 1 \\
\hline \multicolumn{8}{|l|}{ VIREONIDAE } \\
\hline Vireo olivaceus & 47 & ONI & M & 10 & $3.0 \pm 1.94$ & $43.7 \pm 40.86$ & 4 \\
\hline \multicolumn{8}{|l|}{ EMBERIZIDAE } \\
\hline Ramphocelus carbo & 3 & ONI & $\mathrm{R}$ & 2 & $0.5 \pm 0.70$ & $13.5 \pm 6.36$ & 2 \\
\hline Thraupis sayaca & 24 & ONI & $\mathrm{R}$ & 6 & $1.66 \pm 1.86$ & $70.33 \pm 57.10$ & 5 \\
\hline Tangara cayana & 17 & ONI & $\mathrm{R}$ & 6 & $1.83 \pm 2.63$ & $62.33 \pm 39.18$ & 4 \\
\hline Dacnis cayana & 91 & ONI & $\mathrm{R}$ & 10 & $4.2 \pm 2.53$ & $60.0 \pm 28.12$ & 5 \\
\hline \multicolumn{8}{|l|}{ Pulp eaters } \\
\hline \multicolumn{8}{|l|}{ VIREONIDAE } \\
\hline Cyclarhis gujanensis & 3 & INS & $\mathrm{R}$ & 2 & $4.0 \pm 2.82$ & $61.5 \pm 2.12$ & 1 \\
\hline \multicolumn{8}{|l|}{ EMBERIZIDAE } \\
\hline Parula pitiayumi & 3 & INS & $\mathrm{R}$ & 1 & 4 & 97 & 3 \\
\hline Coereba flaveola & 5 & NEC & $\mathrm{R}$ & 3 & $7.33 \pm 2.08$ & $395.33 \pm 134.67$ & 3 \\
\hline Nemosia pileata & 5 & INS & $\mathrm{R}$ & 2 & $4.5 \pm 0.70$ & $52.5 \pm 2.12$ & 3 \\
\hline Piranga flava & 2 & ONI & $\mathrm{R}$ & 1 & 15 & 98 & 1 \\
\hline Zonotrichia capensis & 28 & SE & $\mathrm{R}$ & 8 & $4.75 \pm 4.13$ & $109.75 \pm 77.30$ & 3 \\
\hline
\end{tabular}

${ }^{\mathrm{a}} \mathrm{FRU}=$ frugivore$; \mathrm{ONI}=$ omnivore$; \mathrm{INS}=$ insectivore, $\mathrm{SE}=$ seed eaters, $\mathrm{NEC}=$ nectar eaters $;{ }^{\mathrm{b}} \mathrm{R}=$ resident; $\mathrm{M}=$ migrant; ${ }^{\mathrm{c}}$ Number of observations with complete data on fruit consumed and time spent on plants; ${ }^{\mathrm{d}}$ Mean number of consumed fruits; and ${ }^{\mathrm{e}}$ Mean time spent on plants (s).

(Emberizidae), no significant correlations were found $\left(\mathrm{r}_{\mathrm{s}}=0.54, \mathrm{p}=0.104 ; \mathrm{r}_{\mathrm{s}}=0.30, \mathrm{p}=0.56\right.$ and $\mathrm{r}_{\mathrm{s}}=0.73$, $\mathrm{p}=0.10$, respectively).

Although few agonistic encounters were observed, intra-species encounters $(\mathrm{n}=9)$ predominated over inter-species encounters $(n=2)$. The intra-species encounters were observed with Elaenia spp. $(\mathrm{n}=3), T$. leucomelas $(\mathrm{n}=4), D$. cayana $(\mathrm{n}=1)$ and the rufousbrowed peppershrike, Cyclarhis gujanensis (Gmelin 1789) (Vireonidae) $(\mathrm{n}=1)$, and the inter-species encounters occurred between Elaenia spp. and the brown- crested flycatcher, Myiarchus tyrannulus (Statius Muller 1776) (Tyrannidae) $(\mathrm{n}=1)$, and between $D$. cayana and V. olivaceus $(\mathrm{n}=1)$.

\section{Discussion}

\subsection{Plant characteristics and bird attractiveness}

Most plants whose seeds are dispersed by birds have diaspores that are conspicuously colorful (Van der Pijl, 1982; Willson and Thompson, 1982; Willson and Melampy, 1983), their display of colors probably 
Table 2. Foraging behavior of birds visiting Pera glabrata.

\begin{tabular}{|c|c|c|c|c|c|c|}
\hline \multirow[t]{2}{*}{ Species } & \multicolumn{4}{|c|}{ Methods of taking fruits ${ }^{a}$} & \multicolumn{2}{|c|}{ Handling methods ${ }^{b}$} \\
\hline & Hanging & Picking & Reaching & Stalling & SW & $\mathbf{M}$ \\
\hline Colaptes melanochloros & - & 44 & 11 & - & $\mathrm{x}$ & - \\
\hline Elaenia spp. & - & 19 & 4 & 1 & $\mathrm{x}$ & - \\
\hline Myiarchus ferox & - & 5 & - & - & $\mathrm{x}$ & - \\
\hline Myiarchus tyrannulus & - & 9 & - & 12 & $\mathrm{x}$ & - \\
\hline Empidonomus varius & - & 8 & - & 2 & $\mathrm{x}$ & - \\
\hline Antilophia galeata & - & 8 & 4 & 1 & $\mathrm{x}$ & - \\
\hline Cyanocorax chrysops & - & 9 & 16 & - & $\mathrm{x}$ & - \\
\hline Turdus leucomelas & - & 49 & 8 & - & $\mathrm{x}$ & - \\
\hline Turdus amaurochalinus & - & 33 & 1 & - & $\mathrm{x}$ & - \\
\hline Cyclarhis gujanensis & - & 7 & 1 & - & - & $\mathrm{x}$ \\
\hline Vireo olivaceus & 1 & 24 & 10 & 2 & $\mathrm{x}$ & - \\
\hline Parula pitiayumi & - & 3 & 1 & - & - & $\mathrm{x}$ \\
\hline Coereba flaveola & - & 19 & 3 & - & - & $\mathrm{x}$ \\
\hline Nemosia pileata & - & 7 & 2 & - & - & $\mathrm{x}$ \\
\hline Piranga flava & - & 12 & 3 & - & - & $\mathrm{x}$ \\
\hline Ramphocelus carbo & - & 1 & - & - & $\mathrm{x}$ & - \\
\hline Thraupis sayaca & - & 8 & 2 & - & $\mathrm{x}$ & - \\
\hline Tangara cayana & - & 4 & 6 & 1 & $\mathrm{x}$ & - \\
\hline Dacnis cayana & - & 32 & 10 & - & $\mathrm{x}$ & - \\
\hline Zonotrichia capensis & - & 29 & 9 & - & - & $\mathrm{x}$ \\
\hline
\end{tabular}

${ }^{a}$ Hanging (bird's entire body and legs stay under the perch with the ventral side up); Picking (the bird takes the fruits close to their perching without assuming special positions); Reaching (the bird extends its body out or down from the perch); Stalling (the bird captures the fruit while flying, pausing briefly in front of the fruit) (Moermond and Denslow, 1985); e ${ }^{\mathrm{b}} \mathrm{SW}=\mathrm{Fruits}$ are swallowed whole; $\mathrm{M}=$ Fruits are mashed and the seeds are dropped on parental plants.

having evolved to attract the attention of the dispersers (Ridley, 1930; Van der Pij1, 1982). Many species of plants, including $P$. glabrata, have displays with two or more colors, in such a way that the coloration of the mature diaspore contrasts with the coloration of the non-mature ones or with accessory structures (such as capsules or pedicels), increasing the attraction to the dispersers (Willson and Thompson, 1982; Fuentes, 1995).

P. glabrata presents a visible color contrast, created by the red aril that partially covers the black seed, which contrasts with the dark brown dry fruit. The large number of bird visits to plants of this species suggests that such a display is quite efficient in attracting dispersers, in addition to demonstrating that its oily arils are an important food resource for the birds.

The number of fruits can influence the number of bird visits, because plants with fewer fruits may be less visible or may not guarantee a sufficient energy return (Foster, 1990). For P. glabrata, the absence of a correlation between the number of fruits and the number of visits by birds suggests that other factors besides the number of fruits may be influencing the frequency of visits to individual plants, such as geographic location, presence of bird territories, or proximity to other fruit- ing plants, co-specific or not (Levey et al., 1984; Foster, 1990).

\subsection{Bird attributes and dispersal}

The success of the dispersal by the different species of birds may depend on their fruit-handling behavior (Levey, 1987; Traveset, 1994). In this study, the species observed swallowing the diaspores were considered to be potential seed dispersers.

As previously demonstrated by Levey (1987), some birds of the sub-family Thraupinae (Emberizidae) can act as dispersers of small fruits whose seeds cannot be easily removed from the pulp. However, they can remove the pulp of larger fruits and let the seeds fall on the plants. Our observations reinforce this hypothesis. Although $T$. sayaca, T. cayana and D. cayana have not acted as dispersers of the propagules of Copaifera langsdorffii (Desf. 1821) (Caesalpiniaceae) (Motta-Junior and Lombardi, 1990) and Didymopanax macrocarpum (Cham. and Schltdl, 1826) (Araliaceae) (Francisco and Galetti, unpubl.), the widths of which are 9.6 and $7.86 \mathrm{~mm}$, respectively, they did prove to be potential dispersers of the small propagules of $P$. glabrata $(4.38 \mathrm{~mm})$, swallowing them whole and increasing the possibility of the seeds being regurgitated and/or defecated far from the parent plants, and avoiding the disproportionate mortality rates 
from predation and competition in these locales (Janzen, 1970; Connell, 1971).

The probability of a bird swallowing a fruit whole may be limited by its gape width in relation to the size of the fruit (Wheelwright, 1985; Mazer and Wheelwright, 1993). Although species such as Z. capensis, hepatic tanager, Piranga flava (Vieillot, 1822) (Emberizidae) and hooded tanager, Nemosia pileata (Boddaert, 1783) (Emberizidae) are probably able to swallow the propagulas of $P$. glabrata, these birds handle the seeds to extract the aril, letting them fall on the plants. This is probably due to behavioral aspects, since these species are not specialists in the consumption of fruit, which are included in their diet only occasionally. The ease of extracting the aril, which is loosely attached to the seed, may have also contributed, since $N$. pileata was observed swallowing the fruits of Myrsine lancifolia (Ruiz and Pav. 1825) (Myrsinaceae) whole, whose width is approximately $4 \mathrm{~mm}$ but has pulp that is firmly attached to the seed (Francisco and Galetti, 2001).

Thirty-six (16.14\%) of the 223 bird species registered in the study area are migratory, staying in that area during the months from September to April, which coincides with the fruiting season of P. glabrata. Among them, $V$. olivaceus made an important contribution to the dispersion of $P$. glabrata, as also previously observed for Cabralea canjerana (Vell., 1843) (Meliaceae) in an Atlantic Forest fragment in southeast Brazil (Pizo, 1997). Important contribution of migratory species for seed dispersal was also reported by Guarea glabra (Vahl, 1807) in Panama (Howe and De Steven, 1979), and this may confer an advantage to the plant due to the increased number of potential dispersers.

Information regarding the variation in the number of visits to the plants at different times of the day can contribute to the choice of the most appropriate time to conduct observations, as well as reveal the periods of frugivore activity. Variations in the number of visits throughout the day were previously recorded by Howe (1977) and Kantak (1981). The uniform distribution of the visits throughout the day, as well as the low number of antagonistic encounters, demonstrates the absence of temporal competitive exclusion among the birds that composed the guild of species that consumed $P$. glabrata, as well as the absence of preferential times among the species for foraging.

The different species of birds can remain on the plants just long enough to eat, or they may prolong their visits in such a way that the seeds of the fruits consumed pass through the digestive tract and are eliminated on the same plants (Pratt and Stiles, 1983; Wheelwright, 1991). The lack of a correlation between the length of stay on the plants and the number of fruits consumed for species such as T. leucomelas, $T$. sayaca e $T$. cayana suggests that these birds remain on the plants longer than would be necessary only to feed themselves. Nevertheless, the periods the birds remained on the plants were, on average, shorter than three minutes, diminishing the number of seeds eliminated over the adult plants.

\subsection{Birds and aril interactions in the cerrado}

Previous studies on frugivory and seed dispersal in the Brazilian cerrado (Motta-Junior and Lombardi, 1990; Francisco and Galetti, 2001; Cazetta et al., 2002; Francisco and Galetti, 2002a, 2002b) have shown that arils may constitute an important feeding resource for birds in this ecosystem. It can be demonstrated by the high number of bird visits on plants and high rates of propagule consumption, not only by primarily frugivorous birds, but also by generalists and some primarily insectivorous species, which probably complement their diets with fruits, especially in periods of insect scarcity. In this same study area, the average number of visits per hour of birds consuming diaspores (in $60 \mathrm{~h}$ focal observation periods) was $3.31 \pm 4.42$ for Myrsine lancifolia (Myrcinaceae) (Francisco and Galetti, 2001), $5.8 \pm 5.7$ for Ocotea pulchella (Martius 1830) (Lauraceae) (Francisco and Galetti, 2002a), $4.01 \pm 4.88$ for Davilla rugosa (Poir. 1812) (Dilleniaceae) (Francisco and Galetti, 2002b) and 31.3 \pm 19.49 for Didymopanax macrocarpum (Araliaceae) (unpubl.). The total number of bird species recorded consuming fruits on these plants was 35 , which represents $15.7 \%$ of the species occurring in this area.

The number of bird species consuming $P$. glabrata fruits (20 species) was the largest one, compared to the other plants previously analyzed in the study area, which suggests that its oil-rich arils may constitute an important feeding resource, especially because its fruiting period coincides with the breeding season of most resident and migratory species.

It has been long recognized that forest fragmentation may affect faunal and flora interactions (Saunders et al., 1991). For instance, in the Brazilian Atlantic forest, a remarkable decline from largest to smallest fragments in the relative number of Myrtaceae, Lauraceae, Rubiaceae and Sapotaceae trees (Tabarelli et al., 1999) was found, which are among the most important plant families for frugivore birds in this ecosystem (Galetti and Pizo, 1996). This alteration on richness and abundance of vertebrate dispersed trees will ultimately result in disperser diversity decline, and vice-versa (Tabarelli et al., 1999).

Oil-rich arils are typical of plants with specialized seed dispersal systems (Howe, 1993). However, the propagules of $P$. glabrata are small and can be dispersed by small and generalist birds. Although most of the large and specialized frugivores are already extinct in the studied fragment, the generalist birds presented high frequencies of visits, high rates of consumption, and short stays on the plants, increasing the chances of the seeds being regurgitated and/or defecated far from the parent trees, where predation rate and competition are lower (Janzen, 1970; Connell, 1971).

The large number of species recorded as potential seed dispersers of $P$. glabrata, being most of them very abundant even in Brazilian antropic locations (Zimmerman, 
1996; Krugel and Behr, 1999), may guarantee seed dispersal of this plant in small fragments and regenerating areas. The Brazilian cerrado is considered one of the six most important hot spots on earth, and a significant portion of this area is represented by small fragments and human dominated areas (Cavalcanti, 1988; Myers et al., 2000). Restoration plans in the cerrado must emphasize the maintenance of bird-plant interactions in order to reconstruct self-sustainable ecosystems. We suggest that the characteristics presented by $P$. glabrata make this plant adequate for use in managed reforestations.

Acknowledgments - We are grateful to Dra. Maria Inês Salgueiro Lima for identification of the plant species. M.R. Francisco and V.O. Lunardi were supported by CAPES and M. Galetti by FAPESP and CNPq (Bolsa de Produtividade).

\section{References}

AYRES, M., AYRES-JÚNIOR, M., AYRES, DL. and DOS SANTOS, AS., 2000. BIOESTAT: aplicações estatísticas nas áreas de ciências biológicas e médicas. Sociedade Civil Mamiraua \& CNPq, Manaus.

CARDOSO, JMS. and TABARELLI, M., 2000. Tree species impoverishment and the future flora of the Atlantic Forest of northeast Brazil. Nature, vol. 404, no. 6773, p. 72-74.

CAVALCANTI, RB., 1988. Conservation of birds in the cerrado of central Brazil, p. 59-66. In Goriup, PD. (ed.), Ecology and Conservation of Grassland Birds. Cambridge: ICBP Technical Publication, $\mathrm{n}^{\mathrm{o}} 7$.

CAZETTA, E., RUBIN, P., LUNARDI, VO., FRANCISCO, MR. and Galetti, M., 2002. Frugivoria e dispersão de sementes de Talauma ovata (Magnoliaceae) no sudeste brasileiro. Ararajuba, vol. 10, no. 2, p. 199-206.

CONNELL, JH., 1971. On the role of natural enemies in preventing competitive exclusion in some marine animals and in rain forest tree, p. 298-312. In den BOER, PJ. and GRADWELL, PR. (ed.), Dynamics of populations, PUDOC, Wageningen.

FOSTER, MS., 1987. Feeding methods and efficiencies of selected frugivorous birds. Condor, vol. 89, p. 566-580.

-, 1990. Factors influencing bird foraging preferences among conspecific fruit trees. Condor, vol. 92, p. 844-854.

FRANCISCO, MR. and GALETTI, M., 2001. Frugivoria e dispersão de sementes de Rapanea lancifolia (Myrsinaceae) por aves numa área de cerrado do Estado de São Paulo, sudeste do Brasil. Ararajuba, vol. 9, no. 1, p. 13-19.

-, 2002a. Aves como potenciais dispersoras de sementes de Ocotea pulchella Mart. (Lauraceae) numa área de vegetação de cerrado do sudeste brasileiro. Rev. Bras. Bot., vol. 25, no. 1, p. 11-17.

-, 2002b. Consumo de frutos de Davilla rugosa (Dilleniaceae) por aves numa área de cerrado em São Carlos, Estado de São Paulo. Ararajuba, vol. 10, no. 2, p. 193-198.

FUENTES, M., 1995. The effect of unripe fruits on ripe fruit removal by birds in Pistacia terebinthus: flag or handicap? Oecologia, vol. 101, no. 1, p. 55-58

GALETTI, M. and PIZO, MA., 1996. Fruit eating birds in a forest fragment in southeastern Brazil. Ararajuba, vol. 4, no. 2, p. $71-79$.
GALETTI, M. and STOTZ, D., 1996. Miconia hypoleuca (Melastomataceae) como espécie-chave para aves frugívoras no sudeste do Brasil. Rev. Bras. Biol., vol. 56, no. 2, p. 435-439.

GALETTI, M. and ALEIXO, A., 1998. Effects of harvesting of a keystone palm on frugivores in the Atlantic Forest of Brazil. J. Appl. Ecol., vol. 35, no. 2, p. 286-293.

HERRERA, CM., JORDANO, P., LÓPEZ-SORIA, L. and AMAT, JA., 1994. Recruitment of a mast-fruiting, bird-dispersed tree: bridging frugivore activity and seedling establishment. Ecol. Monogr., vol. 64. no. 3, p. 315-344.

HOWE, HF., 1977. Bird activity and seed dispersal of a tropical wet forest tree. Ecology, vol. 58, no. 3, p. 539-550.

HOWE, HF. and De STEVEN, D., 1979. Fruit production, migrant bird visitation, and seed dispersal of Guarea glabra in Panama. Oecologia, vol. 39, no. 2, p. 185-196.

HOWE, HF., 1984. Implications of seed dispersal by animals for tropical reserve management. Biol. Conserv., vol. 30, no. 3, p. 261-281.

-, 1993. Specialized and generalized dispersal systems: where does the "paradigm" stand? Vegetatio, vol. 107/108, p. 3-13.

IZHAKI, I., 2002. The role of fruit traits in determining fruit removal in East Mediterranean ecosystems, p. 161-175. In Levey, DJ., Silva, WR. and Galetti, M. (ed.), Dispersal and Frugivory: Ecology, Evolution and Conservation. Wallingford, UK: CAB International Publishing.

JANZEN, DH., 1970. Herbivores and the number of tree species in tropical forests. Am. Nat., vol. 104, p. 501-528.

JORDANO, P., 1992. Fruits and frugivory, p. 105-156. In FENNER, M. (ed.), Seeds: the ecology and regeneration in plant communities. Wallingford: CAB International.

KANTAK, GE., 1981. Temporal feeding patterns of some tropical frugivores. Condor, vol. 83, p. 185-187.

KRUGEL, MM. and BEHR, ER., 1999. Consumo de frutos de Alchornia triplinervia (Euphorbiaceae) por aves em fragmentos florestais urbanos de Maringa, Paraná. Biotemas, vol. 12, no. 1, p. $149-155$.

LEVEY, DJ., MOERMOND, TC. and DENSLOW, JS., 1984. Fruit choice in Neotropical birds: the effect of distance between fruits on preference patterns. Ecology, vol. 65, no. 3, p. $844-850$.

LEVEY, DJ., 1987. Seed size and fruit-handling techniques of avian frugivores. Am. Nat., vol. 129, no. 4, p. 471-485.

LORENZI, H., 1998. Árvores brasileiras: manual de identificação e cultivo de plantas arbóreas nativas do Brasil, Nova Odessa: Editora Plantarum, vol. 1, 368p.

MARINI, MA., MOTTA-JUNIOR, JC., VASCONCELLOS, LAS. and CAVALCANTI, RB., 1997. Avian body masses from the cerrado region of central Brazil. Ornitol. Neotrop., vol. 8, no. 1, p. 93-99.

MAZER, SJ. and WHEELWRIGHT, NT., 1993. Fruit size and shape: allometry at different taxonomic levels in bird-dispersed plants. Evol. Ecol., vol. 7, p. 556-575.

MOERMOND, TC. and DENSLOW, JS., 1985. Neotropical avian frugivores: patterns of behavior, morphology, and nutrition, with consequences for fruit selection. Ornithol. Monogr., vol. 36, p. 865-897. 
MOTTA-JUNIOR, JC., 1990. Estrutura trófica e composição das avifaunas de três hábitats terrestres na região central do estado de São Paulo. Ararajuba, vol. 1, no. 1, p. 65-71.

MOTTA-JUNIOR, JC. and LOMBARDI, JA., 1990. Aves como agentes dispersores da copaíba (Copaifera langsdorffi, Caesalpiniaceae) em São Carlos, estado de São Paulo. Ararajuba, vol. 1, no. 1, p. 105-106.

MOTTA-JUNIOR, JC. and VASCONCELLOS, LAS., 1996. Levantamento das aves do campus da Universidade Federal de São Carlos, estado de São Paulo, Brasil. In VII Sem. Reg. Ecologia, I: 159-171. Anais. São Carlos, 7 a 10 de março.

MYERS, N., MITTERMEIER, RA., MITTERMEIER, CG., FONSECA, GAB. and KENT, J., 2000. Biodiversity hotspots for conservation priorities. Nature, vol. 403, no. 6772, p. 853-858.

PAESE, A., 1997. Caracterização e análise ambiental do campus da Universidade Federal de São Carlos (UFSCar), São Carlos, SP. (Master Thesis) - Universidade Federal de São Carlos, São Carlos, 84p.

PASSOS, L. and OLIVEIRA, PS., 2002. Ants affect the distribution and performance of seedlings of Clusia criuva, a primary bird dispersed rain forest tree. J. Ecol., vol. 90, no. 3, p. $517-528$.

PINHEIRO, F. and RIBEIRO, JF., 2001. Síndromes de dispersão de sementes em Matas de Galeria do Distrito Federal, p. 335-378. In Ribeiro, JF., Fonseca, CEL. and Sousa-Silva, JC. (ed.), Cerrado: caracterização e recuperação de Matas de Galeria, EMBRAPA, Ministério da Agricultura, Pecuária e Abastecimento e Ministério do Meio Ambiente, Planaltina.

PIZO, MA., 1997. Seed dispersal and predation in two populations of Cabralea canjerana (Meliaceae) in the Atlantic Forest of southeastern Brazil. J. Trop. Ecol., vol. 13, p. 559-578.

-, 2004. Frugivory and habitat use by fruit-eating birds in a fragmented landscape of southeast Brazil. Orn. Neotr., vol. 15, p. $117-126$.

PRATT, TK. and STILES, EW., 1983. How long fruit-eating birds stay in the plants where they feed: implications for seed dispersal. Am. Nat., vol. 122, no. 6, p. 797-805.

RIBON, R., SIMON, JE. and MATTOS, GT., 2003. Bird extinctions in Atlantic forest fragments of the Viçosa region, Southeastern Brazil. Conserv. Biol., vol. 17, no. 6, p. $1827-1839$.

RIDLEY, HN., 1930. The dispersal of plants throughout the world. Reeve and Co., Ashford, Kent, 744p.

SAUNDERS, DA., HOBBS, RJ. and MARGULES, CR., 1991. Biological consequences of ecosystem fragmentation: a review. Conserv. Biol., vol. 5, no. 1, p. 18-32.

SICK, H., 1997. Ornitologia brasileira. Rio de Janeiro: Editora Nova Fronteira, 912p.

TABARELli, M., MANTOVANI, W. and PERES, C., 1999. Effects of habitat fragmentation on plant guild structure in the montane Atlantic forest of southeastern Brazil. Biol. Conserv., vol. 91, no. 2-3, p. 119-127.

TRAVESET, A., 1994. Influence of type of avian frugivory on the fitness of Pistacia terebinthus L.. Evol. Ecol., vol. 8, p. 618-627.

VAN DER PIJL, L., 1982. Principles of dispersal in higher plants. New York: Springer-Verlag, 215p.

WENNY, DG. and LEVEY, DJ., 1998. Directed seed dispersal by bellbirds in a tropical cloud forest. Proc. Natl. Acad. Sci. USA, vol. 95, p. 6204-6207.

WHEELWRIGHT, NT., 1985. Fruit size, gape width, and the diets of fruit-eating birds. Ecology, vol. 66, no. 3, p. 808-818.

-, 1991. How long do fruit-eating birds stay in the plants where they feed? Biotropica, vol. 23, no. 1, p. 29-40.

WILLIS, EO., 1979. The composition of avian communities in remanescent woodlots in southern Brazil. Pap. Avulsos Zool., vol. 33, no. 1, p. 1-25.

WILLSON, MN. and THOMPSON, JN., 1982. Phenology and ecology of color in bird-dispersed fruits, or why some fruits are red when they are green. Can. J. Bot., vol. 60, p. 701-713.

WILLSON, MF. and MELAMPY, MN., 1983. The effect of bicolored fruit displays on fruit removal by avian frugivores. Oikos, vol. 41, p. 27-31.

ZIMMERMAN, CE., 1996. Observações preliminares sobre a frugivoria por aves em Alchornia glandulosa (Endl. and Poepp.) (Euphorbiaceae) em vegetação secundária. Rev. Bras. Zool., vol. 13 , no. 4 , p. 533-538. 